\title{
Induction of Cellular Efflux by a Galactosamine Polymer from Neurospora crassa
}

\author{
By JOHN W. JENSEN, $\uparrow$ RUTH M. DEBUSK AND A. GIB DEBUSK* \\ Department of Biological Science, Florida State University, Tallahassee, Florida 32306, USA
}

(Received 6 July 1983)

\begin{abstract}
A cationic polymer of D-galactosamine was isolated from culture filtrates of a colonial temperature-sensitive strain of Neurospora crassa. Adsorption of the polymer to the cell surface initiated immediate efflux of low molecular weight metabolites and subsequent loss of viability. The polymer appeared to bind to those sites on the cell surface that normally bind calcium ions. Chemical analysis of the polymer showed it to be partially $N$-acetylated. The polymer had an isoelectric point of 8.4 . Thirty percent of the D-galactosamine residues contained free amino groups. A rapid assay that has potential application for monitoring the effect of a variety of other membrane-active factors on membrane permeability has been developed.
\end{abstract}

\section{INTRODUCTION}

Polycations have been shown to have deleterious effects on biological systems. Among the effects reported are: ultrastructural changes (Quinton \& Philpott, 1973; Mayhew et al., 1973), cell agglutination (Sirica \& Woodman, 1971), and cytotoxicity and altered membrane permeability (Yphantis et al., 1967; Jaspers et al., 1975). Polycations are believed to exert their effects through ionic binding to negatively charged sites on the cell surface (Sela \& Katchalski, 1959).

Galactosaminoglycan is a partially $N$-acetylated cationic polymer of D-galactosamine which can be isolated from cell walls and culture filtrates of several fungi, including Neurospora crassa (Distler \& Roseman, 1960; Harold, 1962; Reissig \& Glasgow, 1971). The biological role of the polymer isolated from $N$. crassa may involve the regulation of growth and hyphal morphology (Reissig \& Glasgow, 1971 ; Springer \& Srb, 1978). The polymer has been shown to adsorb to the cell surface of this fungus and to elicit alterations in both membrane permeability and viability (Glasgow \& Reissig, 1974).

In the work described here we examined the effects on membrane permeability and viability of adsorption of galactosaminoglycan to $N$. crassa conidia. Exposure to galactosaminoglycan led to a decline in cell viability directly proportional to the duration of exposure to the polymer. Adsorption resulted in a rapid efflux of low molecular weight metabolites, which is believed to be responsible for the deleterious effect of the polymer on viability. The galactosaminoglycaninduced efflux phenomenon led to the development of a rapid assay which can potentially be used for the detection of a variety of membrane-active factors, even in crude preparations. We further report the chemical composition of the purified polymer.

\section{METHODS}

Strains and growth of cultures. The wild-type strain Tatum $a$ (FGSC 621) and the colonial temperature-sensitive strain cot-5 (FGSC 1362) were obtained from the Fungal Genetics Stock Center, Humboldt State University Foundation, Arcata, CA 95521, USA. All strains were maintained on $1 \times$ Vogel medium N supplemented with $2 \%(w / v)$ sucrose and solidified with $2 \%(w / v)$ agar as previously described (Vogel, 1964; DeBusk \& DeBusk, $1980)$.

† Present address: Diabetes and Research Training Center, University of Alabama, Birmingham, Alabama 35294, USA. 
Chemicals. The radiolabelled metabolites 3-O-methyl-D $-\left[\mathrm{U}-{ }^{1+} \mathrm{C}\right] \mathrm{glucose}$ and $\mathrm{D}-\left[\mathrm{U}-{ }^{14} \mathrm{C}\right] \mathrm{glucosamine}$ were obtained from New England Nuclear; $\mathrm{L}-\left[\mathrm{U}-{ }^{1+} \mathrm{C}\right]$ phenylalanine, $\mathrm{L}-\left\{\mathrm{U}^{-14} \mathrm{C}\right.$ larginine and $\left[\mathrm{U}-{ }^{14} \mathrm{C}\right]$ uridine were obtained from Schwarz/Mann (Spring Valley, NY, USA). Carrier amino acids were of the L-stereoisomer and were purchased from Calbiochem-Behring (San Diego, CA, USA). The following metabolites were obtained from Sigma: D-galactosamine. $\mathrm{HCl}$, 3-methyl-2-benzothiazolinone hydrazone. $\mathrm{HCl}$, trinitrobenzenesulphonic acid, chitosan (B-grade), poly-L-lysine, 3-O-methyl-D-glucose, uridine and cycloheximide. Lanthanum nitrate was purchased from Aldrich Chemical Co. (Milwaukee, WI, USA).

Isolation and purification of galactosaminoglycan. Erlenmeyer flasks (1 litre) containing $500 \mathrm{ml}$ Vogel medium $\mathrm{N}$ (Vogel. 1964) supplemented with $2 \%$ sucrose were inoculated with conidia of the cot-5 strain and incubated in the light on a rotary shaker $\left(120\right.$ r.p.m.) at the permissive temperature $\left(25^{\circ} \mathrm{C}\right)$. Under these conditions, galactosaminoglycan production was maximal at 5-6 d. At this time, the media were separated from the cultures by filtration, chilled to $4{ }^{\circ} \mathrm{C}$ prior to the addition of 0.4 volumes of cold $95 \%(\mathrm{v} / \mathrm{v})$ ethanol, and allowed to remain at $4 \mathrm{C}$ overnight. The resultant precipitate was collected by centrifugation $\left(3000 \mathrm{~g}, 20 \mathrm{~min}, 4^{\circ} \mathrm{C}\right)$. The precipitate was resuspended in $25 \mathrm{ml} 10 \%(\mathrm{w} / \mathrm{v})$ trichloroacetic acid, stirred overnight at $4^{\circ} \mathrm{C}$, and then centrifuged $(10000 \mathrm{~g}$, ( h. $4^{\circ} \mathrm{C}$ ). The supernatant was dialysed against distilled water for $48 \mathrm{~h}$ at $4^{\circ} \mathrm{C}$ with three changes of water. The non-dialysable material was lyophilized and stored at room temperature. This procedure yielded $60-80 \mathrm{mg}$ pure galactosaminoglycan polymer per litre of culture filtrate.

Radiolabelled galactosaminoglycan was prepared as above from cultures to which $10 \mu \mathrm{Ci}$ of $\mathrm{D}-\left[\mathrm{U}-{ }^{14} \mathrm{C}\right\}$ glucosamine. $\mathrm{HCl}\left[7 \mathrm{mCi}(259 \mathrm{MBq}) \mathrm{mmol}^{-1}\right]$ were added after $48 \mathrm{~h}$ incubation. The cultures were incubated for an additional 3-4 d.

Accumulation and efflux assays. The methods used for the conidial transport assays have been described by DeBusk \& DeBusk (1980). Determination of radiolabelled substrate incorporated into macromolecules at any given incubation time is described by DeBusk et al. (1981). Assays were done at $25^{\circ} \mathrm{C}$ for $3 \mathrm{~h}$ using the wild-type strain. In all cases the Vogel medium $N$ present in the incubation medium was at a final concentration of $0 \cdot 1 \times$ rather than the standard $\mathrm{I} \times$. The radiolabelled substrates $\mathrm{L}-\left[\mathrm{U}-{ }^{14} \mathrm{C}\right\}$ phenylalanine, $\left.\mathrm{L}-\mathrm{U}-{ }^{14} \mathrm{C}\right]$ arginine, and $3-\mathrm{O}-$ methyl-D- $\left\{\mathrm{U}^{-1+} \mathrm{C}\right.$ ) $\mathrm{glucose}$ were present in the incubation medium at a final concentration of $0.01 \mu \mathrm{Ci}(0.37 \mathrm{kBq})$ per $0.1 \mu \mathrm{mol}$ per $\mathrm{ml}$, and [U-1+C]uridine was present at a final concentration of $0.005 \mu \mathrm{Ci}(0.185 \mathrm{kBq})$ per $0.1 \mu \mathrm{mol}$ per $\mathrm{ml}$. To study the effects of the polymers galactosaminoglycan, chitosan or poly-L-lysine on the accumulation or retention of radiolabelled phenylalanine, arginine, uridine or 3-O-methyl-D-glucose, the polymers were present at a final concentration of 20,50 , and $10 \mu \mathrm{g}$ per $\mathrm{ml}$ of incubation medium, respectively, unless otherwise noted. When the effect on metabolite accumulation was monitored, the polymers were present in the incubation medium at the initiation of the transport assay. When the effect on metabolite retention was monitored, the polymers were added in concentrated form $(200-300 \mu \mathrm{l})$ after accumulation had proceeded for $60 \mathrm{~min}$ in the presence of radiolabelled substrate. An equivalent volume of distilled water was added to the control flask. Where the effect of various salts was assayed, the salts were added in crystalline form before initiation of the transport assay or after $60 \mathrm{~min}$ of incubation of cells in the presence of radiolabelled substrate, as noted in the text. The final concentration of each salt is also noted at the appropriate point in the text.

Two modifications of the basic transport assay were used, (1) to assay biological activity of various fractions during the chemical characterization of the polymer, and (2) to develop the efflux assay designed to detect the effect of putative membrane-active factors on membrane permeability. To assay fractions for biological activity, a $2 \mathrm{ml}$ assay was used. Conidia were suspended in $1 \mathrm{ml}$ containing $0.2 \mathrm{mg}$ (dry wt) conidia and $0.2 \times$ Vogel medium $\mathrm{N}$. The assay was initiated by adding the conidia to test tubes containing $0.5 \mathrm{ml}$ of an $\mathrm{L}-\left[{ }^{14} \mathrm{C}\right]$ phenylalanine solution $[0.04 \mu \mathrm{Ci}(1.48 \mathrm{kBq})$ per $0.4 \mu \mathrm{mol}$ per $\mathrm{ml}]$ and $0.5 \mathrm{ml}$ of the test substance (in distilled water). The tubes were mixed briefly, incubated in a reciprocal-shake water bath for $1 \mathrm{~h}$ at $25^{\circ} \mathrm{C}$, and filtered onto nitrocellulose filters (Millipore, type AA, $0.8 \mu \mathrm{m}$ pore size), washed, dried, and counted as usual (DeBusk \& DeBusk, 1980).

For the efflux assay, conidia ( $5 \mathrm{mg}$ dry wt) were developed to the post-conidial stage by incubation for $3 \mathrm{~h}$ at $25{ }^{\circ} \mathrm{C}$ in $50 \mathrm{ml}$ containing $1 \%$ D-glucose and $1 \times$ Vogel medium $\mathrm{N}$. The post-conidial stage is an early developmental stage in which the activity of the amino acid transport systems is considerably amplified over that of the conidial stage so that an approximately tenfold increase in total amino acid accumulation is achieved (Tisdale \& DeBusk, 1970). Radiolabelled L-arginine [0.01 $\mu \mathrm{Ci}(0.37 \mathrm{kBq})$ per $0.1 \mu \mathrm{mol}$ per $\mathrm{ml}$ final concentration] and cycloheximide $\left(10 \mu \mathrm{g} \mathrm{ml}^{-1}\right.$ final concentration) were added after $3 \mathrm{~h}$, and the cells were allowed to accumulate $\mathrm{L}$-arginine for $60 \mathrm{~min}$. The suspension was then stored at $4^{\circ} \mathrm{C}$ for up to two weeks. The stored cells retained $98-$ $99 \%$ of the accumulated arginine during the two week storage period. To test a substance for its effect on membrane permeability, $2 \mathrm{ml}$ of the $0.1 \mathrm{mg} \mathrm{ml}^{-1}$ radiolabelled conidial suspension were filtered onto nitrocellulose filters, washed twice with cold distilled water, and resuspended in test tubes containing $1 \mathrm{ml}$ of $0.2 \times$ Vogel medium $\mathbf{N}$. When lanthanum nitrate was assayed, the medium $\mathbf{N}$ buffer was replaced with an equal volume of deionized water to avoid formation of lanthanum phosphate precipitates. Assays were initiated by the addition of $1 \mathrm{ml}$ of test substance to the $1 \mathrm{ml}$ cell/Vogel medium $\mathrm{N}$ suspension. The tubes were mixed, incubated for $60 \mathrm{~min}$ at $25{ }^{\circ} \mathrm{C}$ in a reciprocal-shake water bath, and then filtered, washed, dried and counted as usual.

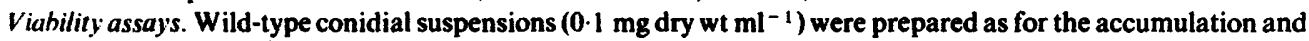
efflux assays. Cells were incubated at $25^{\circ} \mathrm{C}$ with gentle shaking for up to $4 \mathrm{~min}$ in $0.1 \times$ Vogel medium $\mathrm{N}$ 
containing $20 \mu \mathrm{g}$ galactosaminoglycan per $\mathrm{ml}$ of incubation medium. After exposure to galactosaminoglycan, conidia were aseptically filtered onto nitrocellulose filters, washed with $10 \mathrm{ml}$ sterile distilled water, serially diluted in $0.1 \times$ Vogel medium $\mathrm{N}$, and plated onto colony-producing medium containing $1 \times$ Vogel medium $\mathrm{N}, 1.5 \%$ $(\mathrm{w} / \mathrm{v})$ sorbose, $0 \cdot 15 \%$ sucrose and $2 \%$ agar. Colonies were scored after $4 \mathrm{~d}$ at $25^{\circ} \mathrm{C}$. Where the ability of the representative salt $\mathrm{KCl}$ to prevent loss of viability following galactosaminoglycan treatment was examined, conidia were treated as above and at the end of each treatment period an equal volume of $2 \cdot 4 \mathrm{M}-\mathrm{KCl}$ was added to the incubation medium containing galactosaminoglycan to give a final concentration of $1 \cdot 2 \mathrm{M}-\mathrm{KCl}$. After $15 \mathrm{~min}$, conidia were filtered, washed, diluted and plated as above.

Galactosaminoglycan binding assays. Conidia $\left(0 \cdot 1 \mathrm{mg} \mathrm{dry} \mathrm{wt} \mathrm{ml}^{-1}\right.$, final concentration) were incubated for up to $1.5 \mathrm{~h}$ in $0.1 \times$ Vogel medium $\mathrm{N}$ containing $\left[{ }^{14} \mathrm{C}\right]$ galactosaminoglycan at a concentration of $5 \mu \mathrm{g}$ per ml of incubation medium $(320 \mathrm{c} . \mathrm{p} . \mathrm{m}$. per $5 \mu \mathrm{g}$ ). The preparation of radiolabelled galactosaminoglycan is described above, under 'Isolation and purification of galactosaminoglycan'. The assays were done at $25^{\circ} \mathrm{C}$ in a reciprocalshake water bath. At intervals, $5 \mathrm{ml}$ samples were withdrawn, filtered, and washed as for accumulation and efflux assays. Radioactivity was detected by liquid scintillation spectroscopy. Non-specific binding of galactosaminoglycan to the nitrocellulose filters was determined using an incubation medium prepared as above but lacking conidia. The non-specific binding was subtracted from the experimental determinations. When the effect of lanthanum nitrate on galactosaminoglycan binding was examined, the $0.1 \times$ Vogel medium $\mathrm{N}$ was replaced with deionized water.

Characterization of galactosaminoglycan. The isoelectric point of purified $\left[{ }^{14} \mathrm{C}\right]$ galactosaminoglycan was determined by isoelectric focusing for $48 \mathrm{~h}$ at $15^{\circ} \mathrm{C}(300 \mathrm{~V}, 6 \mathrm{~mA})$ on an LKB 810 electrofocusing column according to the method of Vesterburg (1972). The fractions, collected at the rate of $1 \mathrm{ml} \mathrm{min}^{-1}$, were assayed for both $\mathrm{pH}$ and radioactivity.

For amino sugar analysis, non-radiolabelled galactosaminoglycan was hydrolysed in $4 \mathrm{M}-\mathrm{HCl}$ at $100{ }^{\circ} \mathrm{C}$ in sealed tubes purged with nitrogen. Hydrolysis was for $16 \mathrm{~h}$, which resulted in the maximum release of amino sugar. The acid hydrolysate was applied directly to the resin of an amino acid analyser (Beckman model 120B) and eluted with borate buffer ( $\mathrm{pH}$ 7.6) as described by Weber \& Winzler (1969). Hexosamine analysis was done on lyophilized acid hydrolysates according to the total hexosamine procedure of Ludowieg \& Benmaman (1967). The quantity of $N$ unsubstituted D-galactosamine was determined by nitrous acid deaminative degradation which was combusted at pH 4 (Tsuji et al., 1969; Dische \& Borenfreund, 1950; Lindahl et al., 1973).

For amino acid analysis, non-radiolabelled galactosaminoglycan was hydrolysed for $22 \mathrm{~h}$ in $6 \mathrm{M}-\mathrm{HCl}$ at $100{ }^{\circ} \mathrm{C}$ in evacuated tubes purged with nitrogen, lyophilized, and fractionated on an amino acid analyser (Beckman model 120B) using an AA 15 resin and the buffer system described by Spackman (1964). Ascending paper chromatography was done on Whatman no. 1 filter paper with 1-propanol/ethyl acetate/water $(7: 1: 2$, by vol.) as the solvent.

Neutral sugars were estimated by the phenol/sulphuric acid method (Dubois et al., 1956), individual hexoses by gas-liquid chromatography of their aliditol acetates (Lehnhardt \& Winzler, 1968), uronic acids by a carbazole procedure (Davidson, 1966), and free amino groups by the trinitrobenzenesulphonic acid procedure (Habeeb, 1966); total phosphate was analysed by the ashing procedure outlined by Ames (1966).

\section{RESULTS}

\section{Effects of galactosaminoglycan on membrane permeability}

The effect of galactosaminoglycan on membrane permeability was monitored by incubating wild-type $N$. crassa conidia with radiolabelled metabolites in the presence and absence of galactosaminoglycan. Several low molecular weight metabolites were tested: the neutral amino acid L-phenylalanine, the basic amino acid L-arginine, the sugar 3-O-methyl-D-glucose, and the pyrimidine uridine. The effect of galactosaminoglycan on the accumulation and retention of phenylalanine and arginine is characteristic of the effects seen with each of the metabolites tested (Fig. 1). No accumulation of either phenylalanine or arginine occurred in the presence of galactosaminoglycan. Furthermore, when conidia were allowed to transport amino acid before the addition of galactosaminoglycan to the incubation medium, efflux of accumulated amino acid occurred upon addition of the polymer. Efflux was rapid, with maximum loss occurring within $4 \mathrm{~min}$ following the addition of galactosaminoglycan (data not shown). Efflux was minimal at polymer concentrations below $2 \mu \mathrm{g}$ per ml of incubation medium (Fig. 2).

A proportion of the accumulated amino acid was not subject to efflux and was retained by conidia (Fig. 1). The retained amino acids were present in macromolecular form, suggesting that amino acid which has been incorporated into protein is not subject to efflux upon treatment with galactosaminoglycan. When incorporation into protein was prevented by inclusion of the 


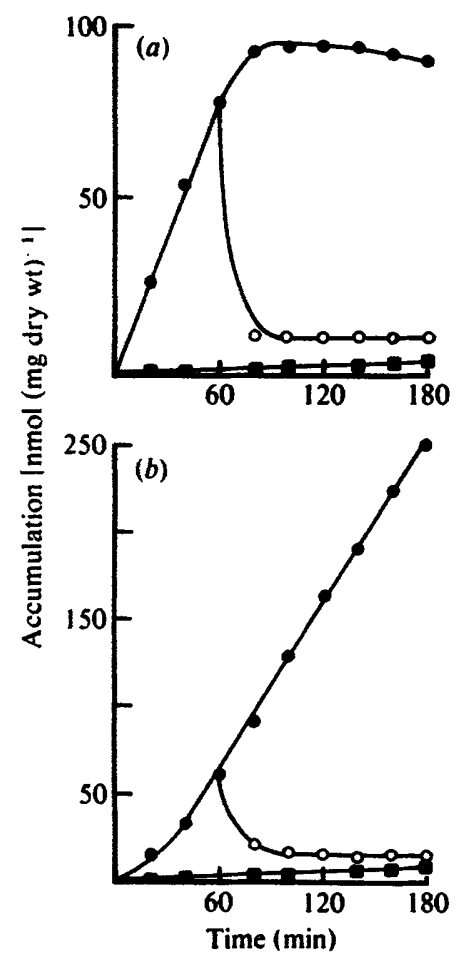

Fig. 1

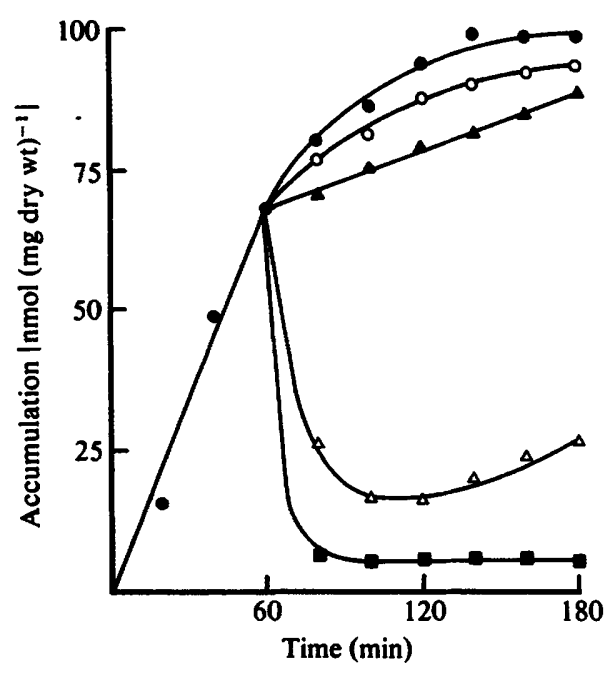

Fig. 2

Fig. 1. Effect of galactosaminoglycan on the accumulation and retention of L-phenylalanine and Larginine by wild-type $N$. crassa. Conidia $\left(0.1 \mathrm{mg} \mathrm{dry} \mathrm{wt} \mathrm{ml}{ }^{-1}\right)$ were incubated at $25^{\circ} \mathrm{C}$ in $0.1 \times$ Vogel medium $N$ containing radiolabelled $\mathrm{L}$-phenylalanine $(a)$ or $\mathrm{L}$-arginine $(b)(0.01 \mu \mathrm{Ci}$ per $0.1 \mu \mathrm{mol}$ per $\mathrm{ml})$ in the absence of galactosaminoglycan (O), in the presence of galactosaminoglycan $\left(20 \mu \mathrm{g} \mathrm{ml}^{-1}\right)$ added at the time the assay was initiated $(\square)$, or in the presence of galactosaminoglycan added 60 min after assay initiation (O). Samples $(0.5 \mathrm{mg}$ dry wt) were removed at $20 \mathrm{~min}$ intervals, washed with three volumes of ice-water, dried, and counted in a gas-flow proportional counter.

Fig. 2. Effect of galactosaminoglycan concentration on the ability of wild-type $N$. crassa to retain Lphenylalanine. Conidia were incubated and assayed as described for Fig. 1. Various concentrations of galactosaminoglycan were added $60 \mathrm{~min}$ after assay initiation: no addition ( $)$ ), $0.5 \mu \mathrm{g}$ galactosaminoglycan per ml of incubation medium (O), $1 \mu \mathrm{g} \mathrm{ml}^{-1}(\Delta), 2 \mu \mathrm{g} \mathrm{ml}^{-1}(\Delta)$, and 3,4,5,10,15 or $20 \mu \mathrm{g} \mathrm{ml}^{-1}$ (a).

protein synthesis inhibitor cycloheximide in the incubation medium, complete efflux of accumulated phenylalanine or arginine was observed (data not shown).

\section{Effect of cations on galactosaminoglycan activity}

The simultaneous presence of one of several salts in the incubation medium eliminated both the ability of galactosaminoglycan to prevent the accumulation of radiolabelled low molecular weight metabolites and the ability to cause efflux of previously accumulated metabolites (Fig. 3). The simultaneous presence of $1.2 \mathrm{M}-\mathrm{KCl}$, a representative of the various salts tested, allowed accumulation and prevented efflux of each of the metabolites previously described, albeit at reduced rates. The ability of $\mathrm{KCl}$ to prevent galactosaminoglycan-induced efflux was directly related to the duration of exposure of conidia to the polymer prior to the addition of the salt (Fig. 4). The concentration of $\mathrm{KCl}$ used in these experiments was that which allowed maximal accumulation of the test metabolite during a standard $3 \mathrm{~h}$ assay in the presence of $20 \mu \mathrm{g}$ galactosaminoglycan per $\mathrm{ml}$ of incubation medium. Maximum accumulation ranged from 90 to 98\% of the level attained in the presence of the salt alone.

Several agents were tested for their ability to prevent efflux of radiolabelled amino acid. In each case a range of concentrations $(0-3.0 \mathrm{M})$ was tested. When the salts $\mathrm{KCl}, \mathrm{LiCl}, \mathrm{MgCl}_{2}$, 


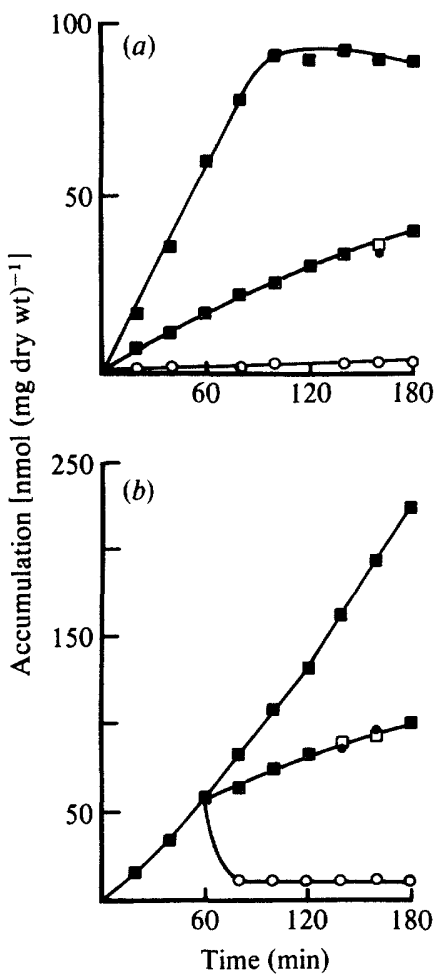

Fig. 3

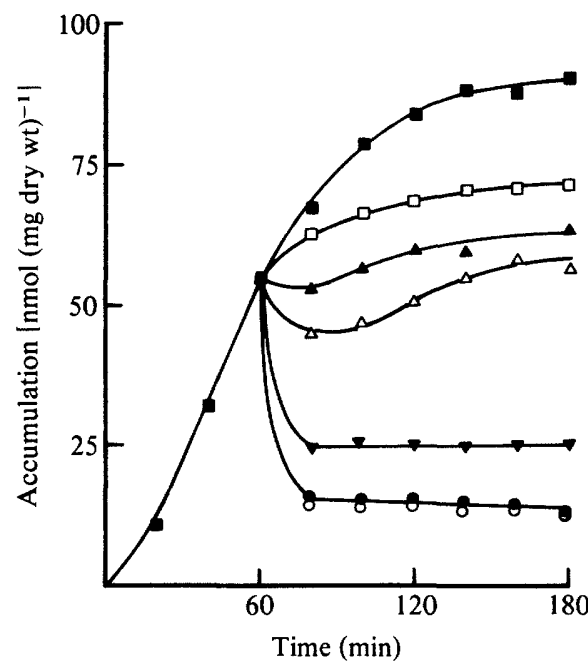

Fig. 4

Fig. 3. Ability of $\mathrm{KCl}$ to interfere with the effects of galactosaminoglycan on amino acid accumulation and retention by wild-type $N$. crassa. Conidia were incubated and assayed as described for Fig. 1. (a) Effect of $\mathrm{KCl}$ on the ability of galactosaminoglycan-treated conidia to accumulate Lphenylalanine. The following additions were made to the incubation medium before the initiation of the transport assay: none (control) $(\square), 1 \cdot 2 \mathrm{M}-\mathrm{KCl}(\mathrm{O}), 20 \mu$ g galactosaminoglycan $\mathrm{ml}^{-1}+1 \cdot 2 \mathrm{M}-\mathrm{KCl}$ $(\square)$, or $20 \mu \mathrm{g}$ galactosaminoglycan $\mathrm{ml}^{-1}(\mathrm{O})$. (b) Effect of $\mathrm{KCl}$ on the ability of galactosaminoglycantreated conidia to retain $\mathrm{L}$-arginine. The following additions were made $60 \mathrm{~min}$ after the transport assay

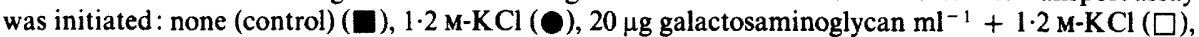
or $20 \mu \mathrm{g}$ galactosaminoglycan $\mathrm{ml}^{-1}(\mathrm{O})$.

Fig. 4. Ability of $\mathrm{KCl}$ to prevent efflux of accumulated L-phenylalanine following exposure of wildtype conidia to galactosaminoglycan. Conidia were incubated and assayed as described for Fig. 1. Galactosaminoglycan $\left(20 \mu \mathrm{g} \mathrm{ml}^{-1}\right)$ was added $60 \mathrm{~min}$ after the transport assay was initiated. $\mathrm{KCl}$ $(1 \cdot 2 \mathrm{M})$ was added simultaneously with galactosaminoglycan $(\square)$, or $0.5(\Delta), 1(\Delta), 2(\nabla)$, or $3(O) \mathrm{min}$ after the addition of galactosaminoglycan. $\square$, Control (no additions); $\mathrm{O}$, no $\mathrm{KCl}$ added.

$\mathrm{MgSO}_{4}$ or $\mathrm{NaCl}$ were added to a conidial suspension that had been exposed to galactosaminoglycan for $30 \mathrm{~s}$, further efflux was halted and accumulation resumed (data not shown). The maximal effective concentration was $1 \cdot 0-1 \cdot 2 \mathrm{M}$ for all salts except $\mathrm{NaCl}$, which was maximally effective at $1.4 \mathrm{M}$. A combination of half the maximal concentration of $\mathrm{KCl}$ plus half the maximal concentration of $\mathrm{NaCl}$ prevented efflux as effectively as did the maximal concentration of either salt. The importance of the ionic nature of the agent was demonstrated by the failure of the non-ionic osmoticum sorbitol to prevent efflux, even at a concentration of $3.5 \mathrm{M}$. Furthermore, $0.4 \mathrm{M}-\mathrm{K}_{2} \mathrm{SO}_{4}$ was as effective as $1.0 \mathrm{M}-\mathrm{KCl}$ or $1.0 \mathrm{M}-\mathrm{MgSO}_{4}$, suggesting that the cationic, rather than the anionic, moiety of the salt molecule was the more important in preventing galactosaminoglycan-induced cellular efflux.

\section{Effects of other polycations on membrane permeability}

The polysaccharide chitosan and the amino acid polymer poly-L-lysine (mol. wt 20000) were tested for their ability to prevent the accumulation of radiolabelled amino acids by $N$. crassa 
conidia. Both polymers gave results similar to those in Fig. 1. Additionally, efflux of accumulated arginine was tested by using poly-L-lysine with results similar to those obtained with galactosaminoglycan (Fig. $3 b$ ). The simultaneous presence of $1.0 \mathrm{M}-\mathrm{KCl}$ in the incubation medium prevented each of the membrane permeability effects observed with these polycations.

\section{Adsorption of galactosaminoglycan to the conidial surface}

The ability of galactosaminoglycan to bind to the surface of $N$. crassa conidia was tested by incubating conidia $\left(0.1 \mathrm{mg}\right.$ dry $\left.\mathrm{wt} \mathrm{ml}^{-1}\right)$ with radiolabelled galactosaminoglycan and measuring the label associated with the conidia as a function of duration of exposure to the polymer. Samples were removed at frequent time intervals. Maximal binding was observed by $0.5 \mathrm{~min}$, and no additional binding was observed after $1.5 \mathrm{~h}$ incubation. A conidial density of $0.1 \mathrm{mg}$ (dry wt) bound $0.8 \mu \mathrm{g}$ galactosaminoglycan. Increasing the concentration of radiolabelled galactosaminoglycan fourfold did not increase the amount of polymer bound within a 5 min period. The simultaneous addition of $1 \mathrm{M}-\mathrm{KCl}$ and radiolabelled galactosaminoglycan reduced binding of the polymer to less than $10 \%$ of that seen with conidia incubated with galactosaminoglycan alone. The addition of $1 \mathrm{M}-\mathrm{KCl}$ to conidia that had been allowed to bind the polymer for $30 \mathrm{~s}$ resulted in the rapid release of the polymer from the conidial surface. $\mathrm{KCl}$ was as effective in releasing galactosaminoglycan that had bound to the conidial surface for $3 \mathrm{~min}$ as it was in releasing polymer that had bound for only $0.5 \mathrm{~min}$.

The binding specificity of galactosaminoglycan was investigated using lanthanum, a calcium antagonist (Takata et al., 1966; Weiss, 1974). The simultaneous presence of $5 \times 10^{-4} \mathrm{M}$ lanthanum nitrate eliminated the effects of galactosaminoglycan on amino acid accumulation and efflux without itself affecting membrane permeability. A concentration of $2 \times 10^{-3} \mathrm{M}^{-}$ lanthanum nitrate completely prevented the binding of galactosaminoglycan to the conidial surface.

\section{Effect of galactosaminoglycan on viability}

When wild-type conidia were treated with galactosaminoglycan before plating onto colonyproducing medium, viability was inversely related to the duration of exposure to the polymer (Fig. 5). When galactosaminoglycan-treated conidia were subsequently treated with $\mathrm{KCl}$, the ability of the salt to prevent loss of conidial viability was also inversely related to the duration of exposure to the polymer (Fig. 5).

\section{Detelopment of a rapid assay for the detection of membrane-active agents}

The positively charged amino acid L-arginine is not readily lost from $N$. crassa conidia following accumulation. The results presented here with galactosaminoglycan, however, showed that arginine could be rapidly lost from cells treated with an agent that alters membrane permeability. These data suggested a ready assay for the detection of biological compounds that alter membrane permeability. The ability of a test substance or crude extracts to alter permeability was assayed by incubating the substance or extract with conidia that had been preloaded with radiolabelled arginine. After a $60 \mathrm{~min}$ incubation, the conidia were filtered, washed, and assayed for radiolabel. A typical set of assay results is shown in Table 1. The assay was very effective in monitoring the presence of galactosaminoglycan in various fractions during purification of the polymer and also served as a preliminary assay for the identification of active fractions of dialysed culture media from human cystic fibrosis fibroblasts (unpublished results). The efflux effects observed with both galactosaminoglycan and cystic fibrosis medium were reversed by the addition of $\mathrm{KCl}$ in a manner similar to the results shown in Fig. 3.

\section{Chemical characterization of galactosaminoglycan}

The ethanol/trichloroacetic acid treatment of culture filtrates from the colonial temperaturesensitive strain cot-5 grown in the presence of $\mathrm{D}-\left[^{1+} \mathrm{C}\right]$ glucosamine yielded radiolabelled galactosaminoglycan polymer for chemical analysis. Purity of the polymer was determined by isoelectric focusing. A single peak, containing both radiolabel and biological activity, focused at a pl of 8.4. The purified polymer was composed of $97.2 \%$ D-galactosamine (as anhydrous D- 


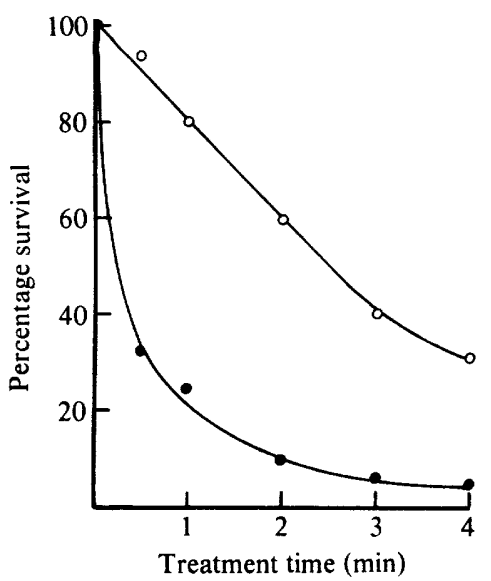

Fig. 5

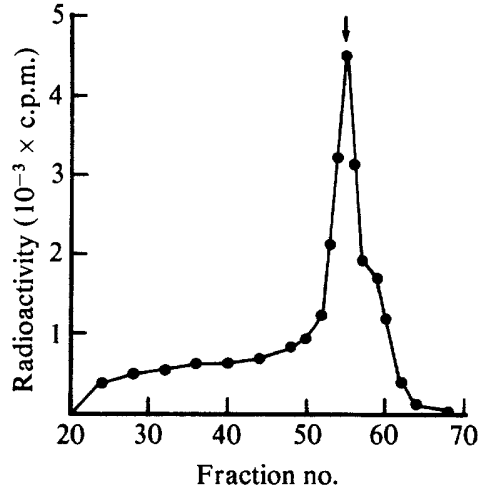

Fig. 6

Fig. 5. Ability of $\mathrm{KCl}$ to prevent loss of viability of conidia treated with galactosaminoglycan. Conidia were incubated as described for Fig. 1. Galactosaminoglycan $\left(20 \mu \mathrm{g} \mathrm{ml}^{-1}\right)$ was added for $0,0 \cdot 5,1,2,3$ or $4 \mathrm{~min}$. The conidia were then filtered, washed three times with sterile ice-water, plated, and scored for viability after $4 \mathrm{~d}$ at $25^{\circ} \mathrm{C} \mathrm{(O)}$. Where the effect of $\mathrm{KCl}$ was monitored, $1.2 \mathrm{M}-\mathrm{KCl}$ was added after each galactosaminoglycan treatment $(O)$; the conidia were incubated an additional 15 min and then filtered, washed, plated, and scored for viability. Viability is expressed as a percentage of the total colonies recovered when cells were not exposed to galactosaminoglycan.

Fig. 6. Gel permeation chromatography of deaminative cleavage products of galactosaminoglycan. $\left[{ }^{14} \mathrm{C}\right]$ Galactosaminoglycan (1 mg: 64000 c.p.m.) was dissolved in $1 \mathrm{ml} \mathrm{0.28} \mathrm{M-acetic} \mathrm{acid} \mathrm{containing}$ $2.9 \mathrm{M}-\mathrm{NaNO}_{2}$ followed by the addition of $0.01 \mathrm{ml} 6 \mathrm{M}$-acetic acid. After $20 \mathrm{~min}$ incubation at $20^{\circ} \mathrm{C}$, a molar excess of ammonium sulphamate was added to terminate the reaction. The entire sample was applied to a Bio Gel P-4 column $(1.6 \times 85 \mathrm{~cm})$. The column was eluted with water, $2.7 \mathrm{ml}$ fractions were collected, and $1 \mathrm{ml}$ samples were counted for radioactivity. The trisaccharide maltotriose was used as a standard and eluted at the position of the arrow. The void and total volumes of the column were 54 and $165 \mathrm{ml}$, respectivelv.

\section{Table 1. Effect of galactosaminoglycan on the ability of wild-type conidia to retain L-arginine}

Conidia ( $5 \mathrm{mg} \mathrm{dry} \mathrm{wt}$ ) were incubated for $3 \mathrm{~h}$ at $25^{\circ} \mathrm{C}$ at a final concentration of $0.1 \mathrm{mg} \mathrm{dry} \mathrm{wt} \mathrm{ml}^{-1}$ in Vogel medium $\mathrm{N}$ containing $1 \% \mathrm{D}$-glucose. Radiolabelled $\mathrm{L}$-arginine $(0.01 \mu \mathrm{Ci}$ per $0.1 \mu \mathrm{mol}$ per $\mathrm{ml})$ and cycloheximide $\left(10 \mu \mathrm{g} \mathrm{ml}^{-1}\right)$ were added, and the conidia were allowed to accumulate arginine for $60 \mathrm{~min}$. Samples $(2 \mathrm{ml})$ were filtered onto nitrocellulose, washed, and resuspended in $0 \cdot 1 \times$ Vogel medium $\mathrm{N}$ containing no addition, galactosaminoglycan $(20 \mu \mathrm{g} \mathrm{ml}-1), 1 \mathrm{M}-\mathrm{KCl}$, or galactosaminoglycan plus $\mathrm{KCl}$. After $60 \mathrm{~min}$ incubation at $25^{\circ} \mathrm{C}$ in a reciprocal-shake water bath, the conidia were filtered, washed, dried, and counted using a gas-flow proportional counter.

\section{Addition}

None

Galactosaminoglycan

$1 \mathrm{M}-\mathrm{KCl}$

Galactosaminoglycan $+1 \mathrm{M}-\mathrm{KCl}$
L-Arginine retention

$$
\text { (c.p.m.) }
$$

200

6190

5980

galactosamine. $\mathrm{HCl}$ ), $0.7 \%$ amino acid, and less than $0.1 \%$ neutral sugar. No D-glucosamine, uronic acid or phosphate was detected. The D-galactosamine residues were $70 \% N$-substituted, presumably by $N$-acetylation. After nitrous acid degradation, which cleaved the polymer at Dgalactosamine residues bearing free amino groups, the major deamination product detected was of trisaccharide size (Fig. 6). These results suggest that $N$-unsubstituted D-galactosamine residues are regularly distributed throughout the polymer and that the polymer is probably comprised of small repeating units. When chromatographed on carboxymethylcellulose 
equilibrated with $0.1 \mathrm{M}$-Tris/acetate buffer $\mathrm{pH} \mathrm{7.3}$ and developed with a linear $\mathrm{NaCl}$ gradient $(0-2 \mathrm{M})$, the polymer eluted as as a single peak at an ionic strength of $0.82 \mathrm{M}$.

Gel filtration and polyacrylamide gel electrophoresis of the undegraded polysaccharide suggested the molecular weight was polydisperse within a range of 70000-120000 (data not shown).

\section{DISCUSSION}

Galactosaminoglycan, a polymer of D-galactosamine, was isolated from culture filtrates of a colonial temperature-sensitive strain of $N$. crassa, cot-5, grown at the permissive temperature, which allows normal hyphal morphology. Galactosaminoglycan has been isolated by Reissig and coworkers (Reissig \& Glasgow, 1971; Glasgow \& Reissig, 1974) from another colonial temperature-sensitive strain of $N$. crassa, cot-1, grown at the non-permissive temperature, which promotes hyphal branching, leading to colonial morphology. The single major difference between the two polymers appears to be the extent to which the D-galactosamine residues are $\mathrm{N}$ substituted, presumably by acetylation. Galactosaminoglycan purified from cot-5 cultures grown at the permissive temperature contained $70 \%$ of the residues $N$-substituted whereas only $25 \%$ of the D-galactosamine residues were $N$-substituted in the polymer produced by cot-1 cultures grown at the non-permissive temperature. The difference in $N$-substitution may reflect simply a strain difference or the fact that the differing growth conditions lead to differing $\mathrm{N}$ acetylation levels of the polymer which in turn lead to alterations in hyphal morphology. Springer \& Srb (1978) have correlated such alterations with the $N$-acetyl content of galactosaminoglycan.

Despite the difference in the extent of $N$-substitution, the two polymers are very similar in their effects on membrane permeability and viability. In the present study, treatment of $N$. crassa conidia with galactosaminoglycan led to loss of viability and to an increase in membrane permeability as measured by the rapid efflux of low molecular weight metabolites. The loss of intracellular small molecules, and presumably ions as well, is believed to underlie the decline in viability following galactosaminoglycan treatment. Adsorption to the conidial surface was essential to the polymer's ability to affect membrane permeability and viability. Binding sites for galactosaminoglycan on the cell surface were rapidly saturated in the presence of lethal concentrations of galactosaminoglycan. The addition of any one of several ionic agents interfered with adsorption and concomitantly interfered with the deleterious effects of the polymer on both permeability and viability. Treatment of cells with the calcium antagonist lanthanum also prevented galactosaminoglycan from binding and from exerting its effects on membrane permeability; lanthanum achieved this at a much lower concentration than the other salts, suggesting that the binding sites for galactosaminoglycan on the cell surface are those normally occupied by calcium.

It has been proposed that the bulk of the ionic interaction between galactosaminoglycan and the cell surface is non-specific and that lethality is initiated by the adsorption of galactosaminoglycan to specific lethal receptors (Glasgow \& Reissig, 1974). In the present study, galactosaminoglycan had little effect on conidial viability or membrane permeability at subthreshold concentrations. These results suggest that a specific quantity of the polymer must bind to the cell surface in order to exert its effects. In addition, both poly-L-lysine and chitosan were observed to have conidial membrane permeability effects which mimicked those of galactosaminoglycan. The results indicate that the inability of conidial membranes to retain small molecules may be a general response to the presence of polycations in media of low ionic strength. Yeast cells have also been shown to lose low molecular weight cytoplasmic constituents in the presence of polycations (Yphantis et al., 1967; Jaspers et al., 1975). The present results favour a mechanism of action based upon the cumulative binding of polycations to the cell surface.

The authors are grateful to Dr John Schutzbach for his assistance with the figures. This research was supported in part by grant $97-7874$ from the Cystic Fibrosis Foundation. 


\section{REFERENCES}

AmEs, B. N. (1966). Assay of inorganic phosphate, total phosphate and phosphatases. Methods in Enzymo$\log y$ 2, 115-118.

Davidson, E. A. (1966). Analysis of sugars found in mucopolysaccharides. Methods in Enzymology 8, 5260.

DeBusk, R. M. \& DeBusk, A. G. (1980). Physiological and regulatory properties of the general amino acid transport system of Neurospora crassa. Journal of Bacteriology 143, 188-197.

DeBusk, R. M., Brown, D. T., DeBusk, A. G. \& Penderghast, R. D. (1981). Alternate mechanism for amino acid entry into Neurospora crassa: extracellular deamination and subsequent keto acid transport. Journal of Bacteriology 146, 163-169.

DisCHE, Z. \& BORENFREUND, E. (1950). A spectrophotometric method for the microdetermination of hexosamines. Journal of Biological Chemistry 184, 517-522.

Distler, J. J. \& Roseman, S. (1960). Galactosamine polymers produced by Aspergillus parasiticus. Journal of Biological Chemistry 235, 2538-2541.

Dubois, M., Gilles, K. A., Hamilton, J. K., Rebers, P. A. \& SMITH, R. (1956). Colorimetric method for the determination of sugars and related substances. Analytical Chemistry 28, 350-356.

Glasgow, J. E. \& Reissig, J. L. (1974). Interaction of galactosaminoglycan with Neurospora conidia. Journal of Bacteriology 120, 759-766.

HABeEB, A. F. S. A. (1966). Determination of free amino groups in proteins by trinitrobenzenesulfonic acid. Analytical Chemistry 14, 328-336.

HAROLD, F. M. (1962). Binding of inorganic polyphosphate to the cell wall of Neurospora crassa. Biochimica et biophysica acta 57, 59-66.

Jaspers, H. T. A., Christianse, K. \& van Steveninck, J. (1975). An improved method for the preparation of yeast enzymes in situ. Biochemical and Biophysical Research Communications 65, 1434-1439.

LEHNHARDT, W. F. \& WINZLER, R. J. (1968). Determination of neutral sugars in glycoproteins by gasliquid chromatography. Journal of Chromatography 34, 471-479.

LiNDAHL, U., BACKSTROM, G., JANSSON, L. \& Hallen, A. (1973). Biosynthesis of heparin II. Formation of sulfamino groups. Journal of Biological Chemistry 248, 7234-7241.

Ludowieg, J. \& Benmaman, D. J. (1967). Colorimeter differentiation of hexosamines. Analytical Biochemistry 19, 80-88.

Mayhew, E., Harlos, J. P. \& Juliano, R. L. (1973). The effect of polycations on cell membrane stability and transport processes. Journal of Membrane Biology 14, 213-228.

Quinton, P. M. \& Philpott, C. W. (1973). A role for anionic sites in epithelial architecture. Effects of cationic polymers on cell membrane structure. Journal of Cell Biology 56, 787-796.

Reissig, J. L. \& Glasgow, J. E. (1971). Mucopolysaccharide which regulates growth in Neurospora. Journal of Bacteriology 190, 882-889.

Sela, M. \& KatChalsKI, A. (1959). Biological properties of poly- $\alpha$-amino acids. Advances in Protein Chemistry 14, 391-478.

Sirica, A. E. \& Woodman, R. J. (1971). Selective aggregation of $\mathrm{L}-1210$ leukemia cells by the polycation chitosan. Journal of the National Cancer Institute 47, 377-388.

SpaCkman, D. S. (1964). Automated amino acid analysis. Federation Proceedings 23, 37.

SPRINGER, W. D. \& SRB, A. M. (1978). Molecular alteration in a Neurospora crassa morphological mutant and its phenocopy. Proceedings of the National Academy of Sciences of the United States of America 75, 1461-1465.

Takata, M., Pickard, W.F., Lettvin, J. Y. \& Moore, J. W. (1966). Ionic conductance changes in the lobster axon membrane when lanthanum is substituted for calcium. Journal of General Physiology 50, 461-471.

Tisdale, J. H. \& DeBusk, A. G. (1970). Developmental regulation of amino acid transport in Neurospora crassa. Journal of Bacteriology 104, 689-697.

Tsuji, J., Kinoshita, T. \& Hoshino, M. (1969). Analytical chemical studies on amino sugars. II. Determination of hexosamines using 3-methyl-2benzothiazolone hydrazone hydrochloride. Chemical and Pharmaceutical Bulletin 17, 1505-1510.

VeSTERBURG, O. (1972). Isoelectric focusing. Methods in Enzymology 22, 389-412.

VoGEL, H. J. (1964). Distribution of lysine pathways among fungi: evolutionary implications. American Naturalist 98, 435-446.

WEBER, P. \& WINZLER, R. J. (1969). Determination of hexosaminitols by ion exchange chromatography and its application to alkali labile glycosidic linkages in glycoproteins. Archives of Biochemistry and Biophysics 129, 534-538.

WEISs, G. B. (1974). Cellular pharmacology of lanthanum. Annual Review of Pharmacology 14, 343-354.

Yphantis, D. A., Dainko, J. L. \& SchlenK, F. (1967). Effect of some proteins on the yeast cell membrane. Journal of Bacteriology 94, 1509-1515. 